\title{
PENGARUH JENIS USAHA, UKURAN PERUSAHAAN, UMUR PERUSAHAAN DAN FINANCIAL LEVERAGE TERHADAP PERATAAN LABA PADA PERUSAHAAN MANUFAKTUR YANG TERDAFTAR DI BURSA EFEK INDONESIA (BEI) TAHUN 2012-2016
}

\author{
Neni Sri Wahyuni Nengsi \\ Universitas Putra Indonesia YPTK Padang, Indonesia \\ Nengsi.academi@gmail.com
}

\begin{abstract}
ABSTRAK
Penelitian ini bertujuan untuk mengetahui seberapa besar Pengaruh Jenis Usaha, Ukuran Perusahaan, Umur Perusahaan, dan Financial Leverage terhadap Perataan Laba pada perusahaan Manufktur Yang Terdaftar di Bursa Efek Indonesia (BEI),". Variabel penelitian yaitu Jenis Perusahaan $\left(\mathrm{X}_{1}\right)$, Ukuran Perusahaan $\left(\mathrm{X}_{2}\right)$, Umur Perusahaaan (X3), Financial Leverage (X4) Perataan Laba (Y) dengan menggunakan metode pengumpulan data yaitu berupa literatur-literatur, kaya ilmiah, penelitian terdahulu, dan menganalisis laporan keuangan dengan sampel 9 perusahaan. Metode analisis yang digunakan adalah Uji Chow, Uji Hausman dan Uji Comman (LM). Untuk uji analisis regresi berganda digunakan yaitu Random Effect Model.

Secara parsial hasil penelitian didapapatkan bahwa variabel Jenis Usaha tidak bepengaruh yang signifikan, Ukuran Perusahaan berpengaruh signifikan, Umur Perusahaan berpengaruh signifikan dan Financial Leverage tidak berpengaruh signifikan terhadap Perataan Laba pada perusahaan manufaktur yang terdaftar di Bursa Efek Indonesia. Sedangkan secara simultan menunjukkan bahwa secara bersama-sama semua variabel independent berpengaruh signifikan terhadap Perataan Laba pada perusahaan manufaktur yang terdaftar di Bursa Efek Indonesia yang di buktikan dengan nilai $\mathrm{Y}=5.893603+0.047983 \mathrm{X} 1+0.281904 \mathrm{X} 2+0.092564 \mathrm{X} 3+0.068756 \mathrm{X} 4+e$.
\end{abstract}

Primary Key: Jenis Usaha, Ukuran Perusahaan, Umur Perusahaan, dan Financial Leverage terhadap Perataan Laba

\section{PENDAHULUAN}

Menurut PSAK No. 1 laporan keuangan merupakan bagian dari proses pelaporan keuangan. Laporan keuangan yang lengkap biasanya meliputi neraca, laporan laba rugi, laporan perubahan posisi keuangan (yang dapat disajikan dalam berbagai cara misalnya, sebagai laporan arus kas, atau laporan arus dana), catatan atas laporan keuangan. Disamping itu juga skedul dan informasi tambahan yang berkaitan dengan laporan tersebut, misalnya, informasi keuangan segmen industry dan geografis serta pengungkapan pengaruh perubahan harga.

Kinerja perusahaan dalam memanfaatkan aktiva untuk menghasilkan laba dapat dilihat dari laporan keuangan yang disajikan oleh manajemen. Manajemen akan memperlihatkan kinerja terbaik perusahaan melalui laporan keuangan yang berisi informasi keuangan dan nantinya akan berguna bagi pengguna informasi untuk pengambilan keputusan ekonomi dan bisnis. . Investor lebih mengarah ke saham perusahaan yang stabil dibandingkan dengan saham perusahaan dengan tingkat fluktuasi laba yang tinggi. Saham perusahaan yang memberikan laba stabil menggambarkan kinerja manajemen yang baik untuk kelangsungan hidup perusahaan.

Kecenderungan untuk memperhatikan laba terdapat dalam laporan laba rugi yang ditentukan banyak peneliti. Situasi ini didasari oleh manajemen terutama dari kalangan manajemen yang kinerjanya diukur berdasarkan informasi tersebut, sehingga mendorong timbulnya dysfunctional behavior (perilaku tidak semestinya) atau membuat kebijakan dengan laporan keuangannya, Dengan kata lain, manajemen akan 
cenderung melakukan tindakan menaikkan laba jika laba relatif rendah dan menurunkan laba jika laba relatif tinggi.

Beberapa fenomena mengenai manajemen laba yang terjadi pada beberapa perusahaan besar. Contoh fenomena manajemen laba yaitu kasus PT Inofisi Infrocom (INVS) pada tahun 2015. Dalam kasus ini Bursa Efek Indonesia (BEI) menemukan indikasi salah saji dalam laporan keuangan INVS periode September 2014. Dalam keterbukaan informasi INVS bertanggal 25 Februari 2015, ada delapan item dalam laporan keuangan INVS yang harus diperbaiki. BEI meminta INVS untuk merevisi nilai aset tetap, laba bersih persaham, laporan segmen usaha, kategori instrumen keuangan, dan jumlah kewajiban dalam informasi segmen usaha. Selain itu, BEI juga menyatakan menajemen INVS salah saji item pembayaran kas kepada karyawan dan penerimaan (pembayaran) bersih utang pihak berelasi dalam laporan arus kas. Pada periode semester pertama 2014 pembayaran gaji karyawan Rp1,9 triliun. Namun, pada kuartal ketiga 2014 angka pembayaran gaji pada karyawan turun menjadi Rp59 miliar.

Selain fenomena perataan laba penelitian yang dilakukan oleh penulis merupakan gabungan dari penelitian sebelumnya yang dilakukan oleh Corelina (2014) Universitas Kristen Petra dengan judul "Analisa Faktor-Faktor yang Berpengaruh Terhadap Perataan Laba (Income Smoothing) Pada Perusahaan Go Publik" Hasil dari penelitian menunjukkan bahwa hasil pengujian univariate untuk $H_{01}$, tidak adanya perbedaan yang signifikan atas ukuran perusahaan dan sector industry antara perusahaan yang tergolong dalam smoothing dan non-smoothing, sedangkan untuk profitabilitas, terdapat perbedaan yang signifikan pada kedua klasifikasi perusahaan. Hasil pengujian univariate tersebut tidak didukung oleh hasil pengujian multivariate pada $H_{02}$, yang menunjukkan bahwa ukuran perusahaan, profitabilitas dan sector industry tidak berpengaruh terhadap perataan laba. Dilakukannya tindakan perataan laba ini biasanya untuk mengurangi pajak, meningkatkan kepercayaan investor yang beranggapan laba yang stabil akan mengurangi kebijakan deviden yang stabil dan menjaga hubungan antara manajer dan pekerja untuk mengurangi gejolak kenaikan laba dalam pelaporan laba yang cukup tajam.

\section{TINJAUAN PUSTAKA 2.1 Perataan Laba}

Corolina (2014) mendefenisikan perataan laba sebagai cara yang digunakan manajemen untuk mengurangi fluktuasi laba yang dilaporkan agar sesuai dengan target yang di inginkan baik melalui metode akuntansi atau transaksi. Perataan laba (income smoothing) menjadi hal yang penting terutama karena praktik ini dapat menimbulkan dysfunctional behavior (perilaku yang tidak semestinya) yang muncul sebagai akibat dari konflik yang timbul antara pihak-pihak yang memiliki kepentingan dengan laporan keuangan perusahaan.

Corolina (2014) menyebutkan bahwa perhatian investor sering kali hanya terpusat pada informasi laba yang diberikan oleh perusahaan bukan hanya terpusat pada informasi laba yang diberikan oleh prusahaan bukan pda prosedur yang digunakan perusahaan untuk menghasilkan informasi laba tersebut, sehingga disini dapat memberikan kesempatan bagi manajemen untuk melakukan tindakan manipulasi laba dengan salah satu caranya adalah melakukan perataan laba (income smoothing). Perataan laba dilakukan manajemen untuk memperbaiki citra perusahaan dimata pihak eksternal yaitu jika perusahaan memiliki resiko rendah, maka variabilitas laba diyakini merupakan factor penting untuk menilai resiko. Selain itu, perataan laba dilakukan manajemen untuk memberikan informasi yang relevan dalam melakukan prediksi terhadap laba dimasa yang akan datang. Perataan laba dilakukan untuk meningkatkan relasi-relasi usaha, meningkatkan perepsi pihak eksternal terhadap kemampuan manajemrsen dan meningkatkan kompensasi manajemen.

\subsection{Jenis Usaha}

Perusahaan public yang terdaftar di Bursa Efek Indonesia dapat dikategorikan kedalam tiga kelompok besar yaitu : perusahaan manufaktur, perusahaan non manufaktur selain usaha bank dan lembaga keuangan lainnya, kelompok usaha bank dan lembaga keuangan. Menurut Agus perusahaan- 
perusahaan perbankan lebih banyak melakukan perataan laba dibandingkan dengan perusahaanperusahaan non perbankan.

Hal ini disebabkan oleh : Okkarisma (2012)

1. Perbankan adalah jenis perusahaan yang berisiko tinggi.

2. Bank merupakan lembaga kepercayaan masyarakat.

3. Bank merupakan perusahaan public.

4. Bank merupakan perusahaan yang high regulated

Perusahaan-perusahaan manufaktur diduga melakukan perataan laba karena perusahaan manufaktur merupakan emiten yang dominan di BEI. Hasil penelitian Dewi (2014) menyatakan bahwa perusahaan dalam industri yang berbeda akan meratakan laba mereka dalam tingkatan yang berbeda. Tingkatan perataan laba yang tinggi ditemukan pada perusahaan yang bergerak di industri minyak dan gas bumi serta obat-obatan. Perusahaan yang bergerak dibidang sektor industri memiliki beberapa kecendrungan yang lebih tinggi dalam melakukan paerataan laba dibandingkan perusahaan yang bergerak pada sektor industri inti.

\subsection{Ukuran Perusahaan}

Ukuran perusahaan merupakan salah satu variabel penting dalam pengelolaan perusahaan. Ukuran perusahaan mencerminkan seberapa besar aset total yang dimiliki perusahaan. Total asset yang dimiliki perusahaan menggambarkan permodalan, serta hak dan kewajiban yang dimilikinya.Semakin besar ukuran perusahaan, dapat dipastikan semakin besar juga dana yang dikelola dan semakin kompleks pula pengelolaannya. Perusahaan besar cenderung mendapat perhatian lebih dari masyarakat luas. Dengan demikian, biasanya perusahaan besar memiliki kecenderungan untuk selalu menjaga stabilitas dan kondisi perusahaan. Untuk menjaga stabilitas dan kondisi ini, perusahaan tentu saja akan berusaha mempertahankan dan terus meningkatkan kinerjanya.

Ukuran perusahaan dapat ditentukan berdasarkan laba, aktiva, tenaga kerja, dan lain-lain, yang semuanya berkorelasi tinggi. Ukuran mempengaruhi leverage jika biaya kebangkrutan merupakan fungsi menurun dari ukuran perusahaan.

\subsection{Umur Perusahaan}

Umur perusahaan menunjukkan seberapa lama perusahaan mampu bertahan. Semakin lama perusahaan dapat bertahan, maka kemungkinan perusahaan untuk mengembalikan investasi akan semakin besar karena sudah berpengalaman. Perusahaan akan menjadi efisien seiring dengan berjalannya waktu. Perusahaan yang mengalami penuan harus mengurangi biaya karena berbagai efek pembelajaran dalam perusahaan lain dengan industry yang sama maupun berbeda. Umur perusahaan dihitung sejak perusahaan tersebut berdiri berdasarkan akta pendirian sampai penelitian dilakukan.

Umur perusahaan adalah lamanya sebuah perusahaan berdiri, berkembang dan bertahan. Umur perusahaan dihitung sejak perusahaan tersebut berdiri berdasarkan akta pendirian sampai penelitian dilakukan. Hasil pengujian yang dilakukan oleh Putra (2015) menyatakan bahwa perusahaan yang sudah lama berdiri, kemungkinan sudah banyak pengalaman yang diperoleh. Semakin lama umur perusahaan, semakin banyak informasi yang telah diperoleh masyarakat tentang perusahaan tersebut. Dan hal ini akan menimbulkan kepercayaan konsumen terhadap produk-produk perusahaan tersebut.

\subsection{Rasio Leverage (Rasio Solvabilitas)}

Untuk menjalankan operasinya setiap perusahaan memiliki berbagai kebutuhan, terutama yang berkaitan dengan dana agar perusahaan dapat berjalan sebagaimana mestinya. Dana selalu dibutuhkan untuk menutupi seluruh atau sebagian dari biaya yang diperlukan, baik dana jangka pendek maupun jangka panjang. Dana juga dibutuhkan untuk melakukan ekspansi atau perluasan usaha tau investasi baru. 
Artinya didalam perussahaan harus selalu tersedia dana dalam jumlah tertentu sehingga tersedia pada saat dibutuhkan. Dalam hal ini, tugas manajer keuanganlah yang bertugas memenuhi kebutuhan tersebut. Menurut Fahmi (2012:127) rasio Leverage adalah mengukur seberapa besar perusahaan dibiayai dengan utang. Penggunaan utang yang terlalu tinggi akan membayarkan perusahaan karena perusahaan akan masuk dalam kategori extrime leverage (utang ekstrim) yaitu perusahaan terjebak dalam tingkat utang yang tinggi dan sulit untuk melepaskan beban utang tersebut. Karena itu sebaiknya perusahaan harus menyeimbangkan beberapa utang yang layak diambil dan dari mana sumber-sumber yang dapat dipakai untuk membayar utang.

Berdasarkan telaah pustaka yang telah dilakukan diatas, maka model pemikiran teoritis yang dikembangkan pada penelitian ini terlihat pada gambar berikut ini :

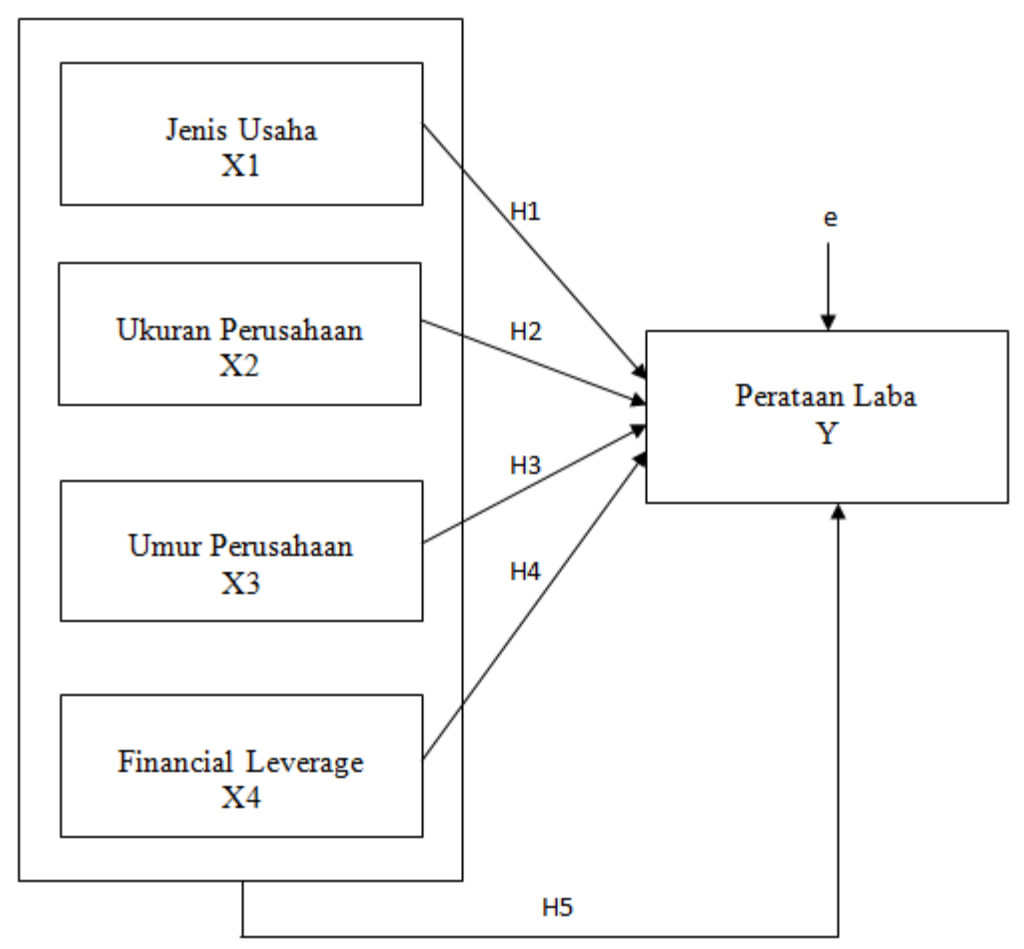

Gambar 2.1: Kerangka Konseptual

\section{METODOLOGI PENELITIAN.}

Dalam penelitian yang penulis lakukan ini, penulis menggunakan desain penelitian kuantitatif karena penelitian yang dilakukan penulis berhubungan dengan angka-angka yang kemudian dilakukan perhitungan dari data-data yang telah diperoleh dari Bursa Efek Indonesia (BEI) dengan periode pengamatan dari tahun 2012 sampai tahun 2016.

\section{Analisis Statistik Deskriptif}

Menurut Ghozali (2016:19) Analisis dengan membandingkan antara bahan bacaan dengan kenyataan yang ditemui dilapangan sehingga dapat menghasilkan solusi yang baik dan optimal. Statistik deskriptif adalah statistik yang digunakan untuk menganalisis data dengan cara mendeskripsikan atau menggambarkan data yang telah terkumpul sebagaimana adanya, tanpa bermaksud membuat kesimpulan yang berlaku untuk umum atau generalisasi. 


\section{Uji Asumsi Klasik}

Apabila model estimasi yang terpilihadalah Random Effect, maka tidak diperlukan uji asumsi klasi Gujarati \& Porte, 2012 dalam (Aulia, 2017:23). Namun, apabila persamaan regresi yang terpilih adalah comman effect dan fixed effect (OLS) maka diperlukan uji asumsi klasik.

\section{Estimate Model Regresi Data Panel Uji Chaw}

Uji chow dilakukan untuk mengetahui apakah model yang digunakan adalah comman effect dan fixed effect. Hipotesis uji chow dalam penelitian ini adalah:

$\mathrm{H}_{0}$ : Comman Effect Model (CEM)

$\mathrm{H}_{1}$ : Fixed Effect Model (FEM)

Dengan ketentuan jika profitabilitas $>0,05$, maka $\mathrm{H}_{0}$ diterima, artinya model yang tepat adalah dengan menggunakan pendekatan comman effect. Tetapi jika profit $<0,05, \mathrm{H}_{0}$ ditolak dan menerima $\mathrm{H}_{1}$, artinya model yang tepat adalah dengan menggukan pendekatan fixed (Arif dan Endah, 2017:33). Pendekatan yang terkaid dalam uji ini adalah:

1. Pendekatan Comman Effect

Dalam menganalisis regresi dengan data panel dapat menggunakan analisi model ordinary least square (OLS) atau Comman Effect Model (CEM). Pendekatan ini adalah yang paling sederhana untuk mengestimasi data panel hanya menggabungkan cross section dan data time series tanpa melihat perbedaan antar waktu dan individu.

2. Pendekatan Fixed Effect

Fixed Effect adalah suatu objek yang memiliki konstanta yang besarannya tetap untuk berbagai periode waktu. Demikian juga dengan koefisien regresi besarannya tetap dari waktu ke waktu.(Winanrno, 2015:9.15).

\section{Uji Housman}

Uji Housman digunakan untuk menentukan apakah model yang paling tepat digunakan adalah model fixed effect atau model random effect. Namun apabila nilai probabilitas $<0,05$, maka $\mathrm{H}_{0}$ ditolak dan menerima $\mathrm{H}_{1}$ yang artinya model yang tepat adalah menggunakan pendekatan fixed effect.

Random Effect digunakan untuk mengatasi kelemahan metode efek tetap yang menggunakan variabel semu, sehingga model mengalami ketidakpastian. Tanpa menggunakan variabel semu, metode efek random menggunakan residual, yang diduga memiliki hubungan antar waktu atau antar objek (Winanarn0, 2015:9.17)

\section{Uji Langrage Multiplier}

Uji Lngrage Multiplier (LM) digunakan untuk mengetahui model mana yang lebih baik, apakah lebih baik estimasi dengan menggunakan model comman effect atau random effect. Hipotesis yang digunakan dalam uji LM adaalah sebagai berikut :

$\mathrm{H}_{0}=$ Model mengikuti comman effect

$\mathrm{H}_{\mathrm{a}}=$ Model mengikuti random effect

Pengambilan keputusan menggunakan nalai probabilitas (Prob.) Breusch Pagan :

Jika nilainya $>0,05$ maka $\mathrm{H}_{0}$ diterima artinya model terpilih adalah $\mathrm{CE}$,

Jika nilai Prob. $<0,05 \mathrm{H}_{0}$ ditolak artinya model terpilih adalah $\mathrm{R}$

\section{Analisis Regresi Linear Berganda}

Analisis regresi linear berganda adalah analisis untuk menguji pengaruh lebih dari satu variabel bebas (indenpenden) terhadap satu variabel terikat (dependen) dan memprediksi variabel dengan menggunakan variabel indenpenden. 
Persamaan regresi linear berganda dengan menggunakan rumus adalah sebagai berikut:

$$
\mathrm{Y}=\mathbf{a}+\mathbf{b} 1 \mathrm{X} 1+\mathbf{b} 2 \mathrm{X} 2+\mathbf{b} 3 \mathbf{X} 3+\mathrm{e}
$$

$\begin{array}{ll}\text { Keterangan: } & =\text { Perataan Laba } \\ \text { Y } & =\text { Konstanta } \\ \mathrm{a} & =\text { Jenis Usaha } \\ \mathrm{X} 1 & =\text { Ukuran Perusahaan } \\ \mathrm{X} 2 & =\text { Umur Perusahaan } \\ \mathrm{X} 3 & =\text { Financial Leverage } \\ \mathrm{X} 4 & =\text { Koefisien regresi untuk masing-masing variabel } \\ \mathrm{b} 1, \mathrm{~b} 2, \mathrm{~b} 3 & =\text { Standar error }\end{array}$

Untuk mempermudah pelaksanaan perhitungan maka penelitian ini akan menggunakan alat bantu SPSS .

\section{Uji Hipotesis}

\section{Uji Secara Parsial (Uji-t)}

Uji t atau uji koefisien regresi secara parsial di gunakan untuk mengetahui apakah secara parsial variabel indenpenden berpengaruh secara signifikan atau tidak terhadap variabel dependen (Priyatno,2012:139). Uji t dapat dilakukan dengan membandingkan antara $\mathrm{t}$ hitung dengan $\mathrm{t}$ tabel. Pengujian menggunakan tingkat signifikan 0,05 .

\section{Uji Secara Simultan (Uji-f)}

Uji f atau uji koefisien regresi secara bersama-sama digunakan untuk mengetahui apakah secara bersama-sama variabel indenpenden berpengaruh signifikan terhadap variabel dependen. Pengujian menggunakan tingkat signifikan 0,05 . Menentukan $\mathrm{f}$ tabel statistic pada tingkat signifikansi 0,05 dengan df 1 (jumlah variabel -1), df 2 (n-k-1).

\section{Pengujian Koefisien Determinasi $\left(\mathbf{R}^{2}\right)$}

Menurut Ghozali (2016:105) Koefisien determinasi berganda $\left(\mathrm{R}^{2}\right)$ atau $\mathrm{R}$ squared berarti secara bersamasama perubahan variable terikat disebabkan oleh variabel bebas atau dengan kata lain $\mathrm{R}$ squared menunjukkan besarnya pengaruh variabel bebas terhadap variabel terikat. Nilai koefisien determinasi ini berkisar antara 0 sampai dengan 1 atau dalam persentase dari mulai 0 sampai dengan $100 \%$.

\section{HASIL DAN PEMBAHASAN 1. Uji Chow}

Uji Chow digunakan untuk menentukan model analisis data panel yang akan digunakan. Uji Chow digunakan untuk memilih antara model Fixed Effect atau model Commond Effect yang sebaiknya dipakai.

$$
\begin{aligned}
& \mathrm{H}_{0} \text { : Common Effect } \\
& \mathrm{H}_{\mathrm{a}} \text { : Fixed Effect }
\end{aligned}
$$

Apabila hasil uji spesifikasi ini menunjukkan probabilitas Chi- square lebih dari 0,05 maka model yang dipilih adalah Common Effect. Sebaliknya, apabila probabilitas Chi-square kurang dari 0,05 maka model yang sebaiknya dipakai adalah Fixed Effect. 
Hasil uji spesifikasi model adalah sebagai berikut :

Tabel 4.1

Hasil Uji Chow Test

\begin{tabular}{|l|r|r|r|}
\hline Redundant Fixed Effects Tests & & \\
\hline Pool: UJI_HOUSMEN & & \\
\hline Test cross-section fixed effects & Statistic & d.f. & Prob. \\
\hline \hline Effects Test & & & \\
\hline \hline Cross-section F & 176.930021 & $(8,32)$ & 0.0000 \\
\hline Cross-section Chi-square & 171.531719 & 8 & 0.0000 \\
\hline
\end{tabular}

Sumber : Hasil olahan eviews 8

Berdasarkan hasil uji diatas, dapat diketahui bahwa probabilitas Chi- square adalah 0.0000 lebih kecil dari 0,05 maka dapat disumpulkan $\mathrm{H}_{0}$ ditolak dan model Fixed Effect lebih baik dibandingkan dengan model Commond Effect. Ketika model yang terpilih adalah Fixed Effect maka perlu dilakukan uji lagi, yaitu Uji Hausman.

\section{Uji Hausman}

Uji Hausman digunakan untuk mengetahui model yang sebaiknya dipakai, yaitu Fixed Effect model (FEM) atau Random Effect model (REM). Hipotesis dalam uji hausman sebagai berikut :

\section{$\mathrm{H}_{0}$ : Random Effect Model \\ $\mathrm{H}_{\mathrm{a}}$ : Fixed Effect Model}

Apabila hasil uji spesifikasi ini menunjukkan prifitabilitas Chi-square lebih dari 0,05 maka model yang dipilih adalah Random Effect. Sebaliknya, apabila profitabilitas Chi- square kurang dari 0,05 maka model yang sebaiknya dipakai adalah Fixed Effect. Hasil estimasi uji hausman adalah sebagai berikut:

Tabel 4.2

\section{Hasil Uji Hausman}

\begin{tabular}{|l|r|r|r|}
\hline Correlated Random Effects - Hausman Test & \\
\hline Pool: KODE & & & \\
\hline Test cross-section random effects & & & \\
\hline \hline & $\begin{array}{r}\text { Chi-Sq. } \\
\text { Statistic }\end{array}$ & Chi-Sq. d.f. & Prob. \\
\hline Test Summary & 0.000000 & 4 & 1.0000 \\
\hline Cross-section random &
\end{tabular}

Sumber : Hasil olahan eviews 8

Berdasarkan hasil uji di atas, dapat diketahui bahwa profitabilitas Chi-square adalah 1.000 lebih besar dari 0,05 maka dapat disimpulkan bahwa model yang digunakan sebaiknya adalah model Random Effect.

\section{Uji LM Test}

Uji LM Tes digunakan untuk memastikan model mana yang akan dipakai, dasar dilakukannya uji ini adalah apabila hasil fixed dan random tidak konsisten. Misalnya pada uji chaw model yang cocok adalah fixed effect model, namun pada saat dilakukannya uji hausman model yang cocok adalah model Random. Sehingga untuk memutuskan model mana yang dipakai maka dilakukanlah yang namanya Uji LM Tes. Hasil estimasi Uji LM Tes sebagai berikut : 
Tabel 4.3

Hasil Uji LM Tes

Residual Cross-Section Dependence Test

Null hypothesis: No cross-section dependence (correlation)

Pool: POOL01

Periods included: 5

Cross-sections included: 9

Total panel observations: 45

Note: non-zero cross-section means detected in data

Cross-section means were removed during computation of correlations

\begin{tabular}{|l|r|r|r|}
\hline \multicolumn{1}{|c|}{ Test } & Statistic & d.f. & Prob. \\
\hline \hline Breusch-Pagan LM & & & \\
\hline Pesaran scaled LM & 49.90548 & 36 & 0.0616 \\
\hline Pesaran CD & 0.578117 & & 0.5632 \\
\hline
\end{tabular}

Sumber : Hasil olahan eviews 8

Berdasarkan tabel diatas maka dapat dilihat nilai Breusch-Pagan LM sebesar 0.0616 berarti besar dari 0,05, maka dapat disimpulkan bahwa model yang digunakan sebaiknya adalah model Random Effect.

Maka dapat disimpulkan penelitian ini menggunakan model Random Effect, dan dapat dilihat dalam tabel sebagai berikut:

Tabel 4.4

Hasil Model yang Digunakan

\begin{tabular}{|l|c|c|}
\hline \multicolumn{1}{|c|}{ Uji } & Keterangan & model yang Terpilih \\
\hline Chaw & Comman dengan fixed & Fixed \\
\hline Hausman & Fixed dengan Random & Random \\
\hline Command (LM) & Comman dengan Random & Random \\
\hline
\end{tabular}

Hasil Regresi Jenis Usaha, Ukuran Perusahaan, Umur Perusahaan, dan Financial Leverage Terhadap Perataan Laba

\begin{tabular}{|l|l|}
\hline Dependent Variable: Y_PL? & \\
\hline Method: Pooled EGLS (Cross-section random effects)
\end{tabular}

Date: 01/08/18 Time: 13:40

Sample: 15

Included observations: 5

Cross-sections included: 9

Total pool (balanced) observations: 45

Swamy and Arora estimator of component variances

White cross-section standard errors \& covariance (d.f. corrected)

WARNING: estimated coefficient covariance matrix is of reduced rank

\begin{tabular}{|c|c|c|c|c|}
\hline Variable & Coefficient & Std. Error & t-Statistic & Prob. \\
\hline $\mathrm{C}$ & 5.893603 & 1.343755 & 4.385921 & 0.0001 \\
\hline X1_JU? & 0.047983 & 0.064644 & 0.742262 & 0.4623 \\
\hline X2_UKURAN? & 0.281904 & 0.105644 & 2.668419 & 0.0110 \\
\hline X3_UMUR? & 0.092564 & 0.010311 & 8.976791 & 0.0000 \\
\hline X4_FINANCIAL? & 0.068756 & 0.053762 & 1.278910 & 0.2083 \\
\hline $\begin{array}{c}\text { Random Effects } \\
\text { (Cross) }\end{array}$ & & & & \\
\hline ROTI--C & 2.694306 & & & \\
\hline SKLT--C & 1.876366 & & & \\
\hline CEKA--C & 0.250052 & & & \\
\hline
\end{tabular}




\begin{tabular}{|c|c|c|c|c|}
\hline INCI--C & -0.007012 & & & \\
\hline STTP--C & -0.411836 & & & \\
\hline GGRM--C & -0.945647 & & & \\
\hline HMSP--C & -1.023537 & & & \\
\hline TCID--C & -1.169258 & & & \\
\hline \multirow[t]{3}{*}{ EKAD--C } & -1.263432 & & & \\
\hline & Effects Spe & cification & & \\
\hline & & & S.D. & Rho \\
\hline \multicolumn{3}{|l|}{ Cross-section random } & 1.016269 & 0.9790 \\
\hline \multicolumn{3}{|l|}{ Idiosyncratic random } & 0.149000 & 0.0210 \\
\hline & Weighted & Statistics & & \\
\hline R-squared & 0.506864 & \multicolumn{2}{|c|}{ Mean dependent var } & 0.738636 \\
\hline Adjusted R-squared & 0.457551 & \multicolumn{2}{|c|}{ S.D. dependent var } & 0.222501 \\
\hline S.E. of regression & 0.163874 & \multicolumn{2}{|c|}{ Sum squared resid } & 1.074191 \\
\hline F-statistic & 10.27840 & \multicolumn{2}{|c|}{ Durbin-Watson stat } & 0.886513 \\
\hline Prob(F-statistic) & 0.000008 & & & \\
\hline
\end{tabular}

Berdasarkan tabel diatas maka dapat dilihat persamaan regresinya yaitu :

$Y=5.893603+0.047983 X_{1}+0.281904 X_{2}+0.092564 X_{3}+0.068756 X_{4}$

Dari persamaan regresi berganda di atas dapat disimpulkan bahwa :

1. Jika diasumsikan nilai dari variabel Jenis Usaha, Ukuran Perusahaan, Umur Perusahaan, dan Financial Leverage sama dengan 0, maka besar output perataan laba adalah 5.893603.

2. Variabel Jenis Usaha mempunyai pengaruh positif terhadap perataan laba dengan koefisien regresi sebesar 0.047983, jika Jenis Usaha dinaikkan satu satuan bobot dengan asumsi Ukuran Perusahaan, Umur Perusahaan dan Financial leverage bernilai 0 maka Perataan Laba akan mengalami peningkatan sebesar 0.047983 .

3. Koefisien regresi veriabel Ukuran Perusahaan mempunyai pengaruh positifterhadap perataan laba dengan koefisien sebesar 0.281904, jika Ukuran Perusahaan dinaikkan satu satuan bobot dengan asumsi Jenis Usaha, Umur Perusahaan dan Financial leverage bernilai 0 maka Perataan Laba akan mengalami peningkatan sebesar 0.281904 .

4. Koefisien regresi veriabel Umur Perusahaan mempunyai pengaruh positifterhadap perataan laba dengan koefisien sebesar 0.092564, jika Umur Perusahaan dinaikkan satu satuan bobot dengan asumsi Jenis Usaha, Ukuran Perusahaan dan Financial leverage bernilai 0 maka Perataan Laba akan mengalami peningkatan sebesar 0.092564 .

5. Koefisien regresi veriabel Financial leverage mempunyai pengaruh positifterhadap perataan laba dengan koefisien sebesar 0.068756, jika Financial leverage dinaikkan satu satuan bobot dengan asumsi Jenis Usaha, Ukuran Perusahaan dan Umur Perusahaan bernilai 0 maka Perataan Laba akan mengalami peningkatan sebesar 0.068756 .

Dari data diatas maka terlihat bahwa perusahaan yang memiliki nilai terbaik yaitu PT ROTI dimana nilai kontantanya sebesar 2.694306 sedangkan untuk nilai konstanta terkecilnya yaitu pada PT EKAD sebesar -1.263432 . Sehingga jika dibuat dalam persamaan maka akan terlihat sebagai berikut :

1. PT ROTI

$Y=8.444059+2.694306+0.047983 X_{1}+0.281904 X_{2}+0.092564 X_{3}+0.068756 X_{4}+e$

2. EKAD

$Y=8.444059-1.2634320+047983 X_{1}+0.281904 X_{2}+0.092564 X_{3}+0.068756 X_{4}+e$ 


\section{DAFTAR PUSTAKA}

Aulia, Triana, Zuhrotun. 2017. "Pengaruh Profitabilitas, Ukuran Perusahaan dan Kinerja Lingkungan Terhadap Corporate Social Responsibility Disclosure Berdasarkan Indikator Global ReportingInititive (Gri) Pada Perusahaan Manufaktur yang Terdaftar di Bursa Efek Indinesia”. Jurnal Akuntansi dan Keuangan, Hal : 1631.

Corolina. "Analisa Faktor-Faktor yang Berpengaruh Terhadap Perataan Laba(Income Smoothing) pada Perusahaan-perusahaan Go Public", Jurnal Jurusan Ekonomi akuntansi Universitas Kristeb Petra, Vol. 7, No. 2, November : 148-162.

Davey, Horward. 2012. “The Effects Of Industry Type, Company Size And Performance On Chinese Campanies' Ic Disclosure: A Research Note". Australasian Accounting, Business And Financial Journal, 5(3), 2012, 107 116.

Dewi, Made Yustiari. 2014. "Pengaruh Ukuran Perusahaan Dan Profitabilitas Pada Praktik Perataan Laba Dengan Jenis Industri Sebagai Variabel Pemoderasi di Bursa Efek Indonesia”,

Fahmi, Irham. 2014. Analisis Laporan Keuangan. Banduang: Alfhabetha

Fahmi, Irham. 2015. Pengantar Manajemen Keuangan. Bandung: Alfhabetha

Ghozali, Imam. 2013. Aplikasi Analisis Multivariate dengan Program IBM SPSS 21. Semarang: Universitas Diponegoro

Horne, James G. Van dan Jhon M. Wachowicz. 2012. Prinsip-prinsip Manajemen Keuangan. Jakarta E- jurnal Akuntansi Universitas Udayana 8.2 (2014): 170-184.Selatan: Salemba Empat

Kasmir. 2010. Analisis Laporan Keuangan. Jakarta: Kencana

Kasmir. 2014. Pengantar Manajemen Keuangan. Jakarta: Rajawali

Maharani, Luh Gede Putri. 2016. "Pengaruh Ukuran, Umur Perusahaan, Struktur Kepemilikan, Dan Profitabilitas Pada Pengungkapan Wajib Laporan Tahunan", E- Jurnal Akuntansi Universitas Udayana, Vol. 41.1 Januari 2016: 34-52.

Mahmud, Nurfarizan Mazhani. 2012. "Income smoothing and Industrial Sector", Elixir International journal: Universitas Teknologi MARA, Malaysia. Elixir Fin. Mgmt. 50(2012) 10248-10252.

Moneque, Eduardo Zandomenigue. et al. 2012. "Effect of Income Smoothing Practies On The Conservation Of Public Companies Listed On The BM\&FBOVESPA". R. Cont. Fin. -USP. Sao paulo, v. 23, n. 58, p. 65-75. Jan./fev./mar./abr. 2012.

Okkarisma, Diastiti. 2012. "Pengaruh Jenis Usaha, Ukuran Perusahaan, dan Financial Leverage terhadap perataan laba pada Perusahaan yang terdaftar di Bursa Efek Indonesia". E-jurnal Universitas Diponegoro Semarang.

Pebriana, Kadek Umi Sukma. "Pengaruh Profitabilitas ,Leverage, Umur Perusahaan, Komposisi Dewan Direksi dan Kepemilikan Institusional pada Pengungkapan Corporate Social Responsibility(CSR) di Bursa Efek Indonesia", Fakultas Ekonomi Universitas Udayana (Unud), Bali.

Putra, I Gede Ari Pratama. 2015. "Pengaruh Profitabilitas, Umur Prusahaan, Kepemilikan institusinal, Komisaris independen, dan Komite Audit Pada Ketepatwaktuan Publikasi Laporan Keuangan Tahunan”, E-Jurnal Akuntansi Universitas Udayana 10.1 (2015) :199-213.

Rifai, Moh. 2015. "Pengaruh Ukuran Perusahaan, Struktur Modal dan Pertumbuhan Perushaan terhadap Profitabilitas Studi pada Perusahaan Manufaktur di BEI Tahun 2010-2012”. E-jurnal Universitas Pandanaran Semarang.

Sanusi, Anwar. 2013. Metodologi Penelitian Bisnis. Jakarta: Salemba Empat

Saringat, Siti Masnah. et al. 2013. "Income Smoothing And Islam: An Evidence From Malaysian Shariah Compliant Compliant Companies". International Journal Of Social And Humanity, Vol. 3, No. 2, March 2013.

Sugiyono, 2016. Metode Penilitian Pendidikan Pendekatan Kuantitatif, Kualitatif, dan R\&D. Bandung: Alfhabetha.

Suhartanto, Dwi. 2015. "Pengaruh Ukuran Perusahaan, Profitabilitas, Leverage, Kepemilikan Publik, Perubahan Harga Saham dan Resiko Bisnis Terhadap Manajemen Laba pada Perusahaan Publik Sektor Keuangan”, Jurnal Ekonomi Bisnis. Vol 20. No. 1, April 2015.

Sunyoto, Dadang. 2013. Analisis Laporan Keuangan Untuk Bisnis (teori dan kasus). Yogyakarta: CAPS

Syafri, Sofyan. 2015. Analisis Kritis Atas Laporan Keuangan. Jakarta: Rajawali

Winarno, Wing Wahyu. 2015. Analisis Ekonometrika dan Statistik dengan Eviews. Yogyakarta: UPPSTIM YKPN

www.idx.co.id

$\underline{\text { www.sahamok.co.id }}$ 